\title{
FEM ANALYSIS OF WORKING CONDITIONS ON THE STRESS AND STRAIN OF LOW-CAPACITY DISC GRANULATOR FRAMES
}

\author{
MICHAŁ BEMBENEK* ${ }^{*}$ KAROL JANKOWICZ \\ AGH University of Science and Technology, al. Mickiewicza 30, 30-059 Krakow, Poland \\ *Corresponding author: bembenek@agh.edu.pl
}

\begin{abstract}
The common practice of frame selection is a simplified way without calculations of the strength and strain conditions. It is particularly popular in the design of small devices. In the case of granulation in a disc granulator, it is necessary to experimentally determine the correct parameters of the process. Therefore, the disc granulator must operate with a wide range of settings of the inclination of the granulator disc axis in relation to the ground. The use of the granulator for laboratory purposes requires also taking into account the loads resulting from its mobility. In response to this the FEM analysis was carried out as to the effect of the working disc position angle on stresses occurring in the laboratory disc granulators LDG300 and DG750 frame. Additionally, analyses of the stresses of the granulator's frames during their lifting and displacing were done. The analyses allowed the researchers to identify the main load that affects the frame design most markedly.
\end{abstract}

Key words: Granulation, Frame deformation analysis, Frame stress analysis, FEM, Disc granulator

\section{INTRODUCTION}

A popular approach in the process of device design is to focus mainly on the design of the operating system and the selection of a proper drive system justified by design assumptions (Baiul, 2019; Karwat et al, 2020). This is the most appropriate approach, as long as it does not neglect the issue of solving the method of mounting the working system and the drive system, thus the solution of the frame structure. In many cases, the frame design process is limited to adopting a certain pre-existing frame solution. Often the design of the frame is based on the experience of the designer, which may lead to oversize the frame as well as excessively increasing its weight, using more material than necessary, and thereby increasing the costs associated with the production of the device. The reason for doing this is the difficulty of carrying out frame strength calculations. In this case, it is helpful to use appropriate engineering tools which provide the strength analy- sis of the tested frame. On the basis of these calculations the selection of its elements or optimization of the existing solution is possible (Malipatil, 2014) and ensuring endurance conditions (Lian, 2016), as well as achieving stiffness and functional assumptions e.g. the appropriate arrangement of working elements. This problem also appears in the design of the disc granulators. In the literature there are a lot of data concerning the selection of the working system, failing to account for the selection of the frame, for which there are no guidelines. Another problem which has been noticed, especially in the case of small devices, is the fact that in the process of designing them additional loads such as the load coming from the movement of the granulator or its handling are not taken into engineering calculations. Therefore, the article attempts to apply a different approach to the frame designing of technological devices on the example of a disc granulators, taking into account the forces acting on the granulator during its displacement, loads coming from the pro- 
cessed material and also loads occurring during lifting.

\section{DISC GRANULATORS DESIGN - AVAILABLE INFORMATION}

Granulation is a popular method of processing bulk materials which is used in industry (Bembenek and Wdaniec, 2019; Bembenek et al., 2020). Nonpressure agglomeration is one of the most popular methods of consolidating bulk materials, which allows obtaining granules with specific properties. This process is popular due to the possibility of obtaining a satisfactory level of integration of the granulated material with relatively low energy consumption and low installation costs (Gluba, 2012). The granulation process can be carried out in devices of different construction solutions. One of the common types of non-pressure granulators apart the fluidizing-bed, drum, vibrating, paddle or tower granulators are disk granulators (Gluba, 2012; Kłassien et al., 1989; Ennis, 2010). The working element of the disc granulator is a rotating cylindrical container with an open top surface. The disc rotates around an axis perpendicular to the plane of the disc surface. The disc axis is usually inclined at the angle of $30^{\circ}$ to $60^{\circ}$ in relation to the ground (continuous granulation) or at the angle of $90^{\circ}$ in relation to the ground (periodic granulation) (Leszczuk, 2014; Piekut, 2018; Kłassien et al., 1989). The rotation speed of the disc is usually in the range from 0.6 to 0.75 of the critical speed. The critical speed is the speed at which the material does not detach from the side walls of the rotating disc of the granulator (Leszczuk, 2014; Korpal, 2005; Ennis, 2010). Disc granulators allow for obtaining homogeneous granules in the terms of a size and a shape. In cases where the appropriate selection of process parameters is made the proper granulation on the entire material load is possible. Due to the continuous work the disc granulators can be included in high efficiency technological lines (Leszczuk, 2014; Kłassien et al., 1989). Many publications are focused on the selection of appropriate parameters of the granulation process for already-existing granulators, often installed in technological lines, others on examining the possibility of granulating the material for new combinations of granulated material and binder. The change of the granulated material or the inclination angle of the granulator disc causes changes in the load values on granulator parts. There is a wealth of information about the possibility of using disc granulators for granulating materials such as: waste materials in the iron and steel industry (Udo, 2018; Burchart-Korol, 2009; Burchart-Korol et al., 2012), coal sludge and dust (Agusta et. al., 2017; Hdger, 2016; Ozga et al., 2018; Obraniak, 2018) or even animal feed (Korpal, 2005). These studies lead to the determination of parameters allowing for the implementation of the process developed in a laboratory to enter into an industrial scale. In the literature there is a small amount of research on the design of granulators. These studies and analyses usually focus on scrapers (Hejft, 2012) and the construction of the granulator discs themselves (Feng, 2012). Researches on scrapers are conducted in order to determine the influence of the scraper settings on the granulation process. In the case of analysis of the structure of the granulator disc they are aimed at reducing the mass of the disc itself, and/or maintaining or improving its stiffness. Strength tests and analyses generally focus on determining the value of stresses occurring in the case of device operation and optimization of its design parameters (Xinhao, 2016; Hatapakki, 2016). There is also no data in the literature on the impact of other external loads on the granulator. An example of this is the calculation of the stress values created when the disc granulator is moved over the surface on which it is located or when it is lifted and moved. It is typical for laboratory and middle size devices, but unprecedented for industrial ones, which may be the reason for the low frequency of this type of analysis consequently leading to a lack of knowledge about their impact on the strength of the device structure.

\section{MATERIALS AND METHODS}

To perform the simulation the LDG 300 and DG750 disc granulators were used. In order to estimate the influence of the disc inclination angle on the stresses in the elements of the granulator frame models of laboratory disk granulator's frames (figure 1), with the design and technological parameters presented in table 1 , were divided into two parts: lower and upper (connected with a chute mounted under the granulator disc in the case of the LDG300 construction). For the LDG300 granulator it was decided to carry out an analysis for the connected elements of the frame and the chute in order to determine the displacement of the chute, and on its 
basis select the appropriate gap between the chute and the granulator disc.

To the model of the upper part of the granulator, forces and torques from the gearmotor, half-coupling the plate itself and the feed located on the granulator plate were applied (figures $2 \mathrm{a}$ and $2 \mathrm{~b}$ ). In the case of the DG750 granulator the loads from the belt gear were taken into account instead of the forces and moments coming from the half-coupling (figures $2 \mathrm{c}$ and $2 \mathrm{~d}$ ). Iron-bearing and iron ore dusts were used as the granulated material. The values of the resultant forces and moments shown in figure 2 are presented in table 2 .

Table 1. The main parameters of LDG300 and DG750 disc granulators.

\begin{tabular}{|l|c|c|}
\hline & LDG300 & DG750 \\
\hline Disc rim height, $\mathrm{mm}$ & 90 & 120 \\
\hline Disc diameter, mm & 300 & 750 \\
\hline Max. disc speed, RPM & 54 & 52.9 \\
\hline Disc fill factor, - & 0.21 & 0.21 \\
\hline Max. material load on the disc, $\mathrm{kg}$ & 9.3 & 85.5 \\
\hline Power of the motor, $\mathrm{kW}$ & 0.18 & 3.0 \\
\hline Gearmotor weight, kg & 7 & 52 \\
\hline Disc weight with accessories, $\mathrm{kg}$ & 8.8 & 93 \\
\hline Weight of the loaded dosing kit, $\mathrm{kg}$ & 11 & 11 \\
\hline $\begin{array}{l}\text { Weight of a set of bearing hous- } \\
\text { ings with bearings, kg }\end{array}$ & 1.5 & 12.3 \\
\hline Lower frame weight, kg & 3.5 & 81.5 \\
\hline Mass acting on the lower frame, $\mathrm{kg}$ & 11.5 & 347.5 \\
\hline
\end{tabular}
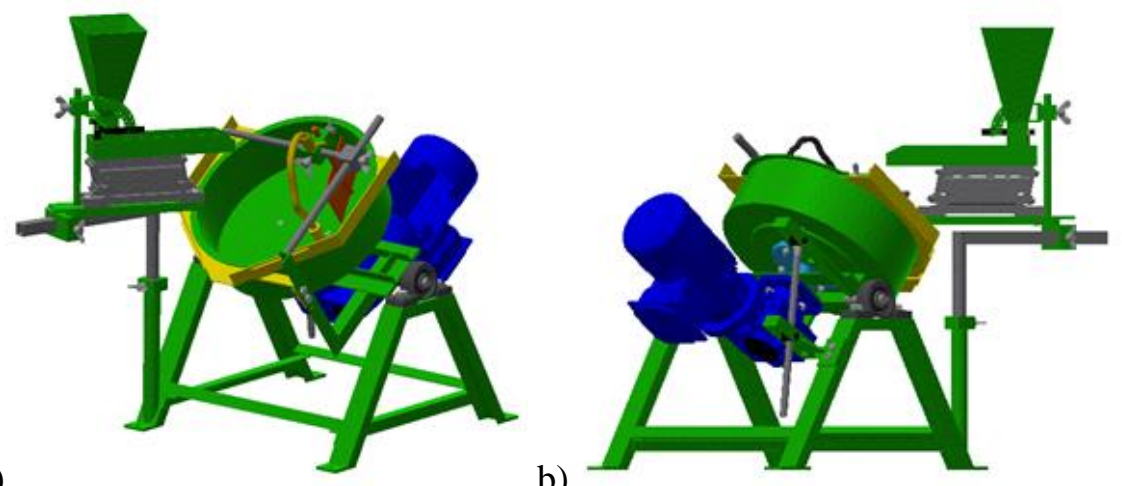

b)

a)

c)
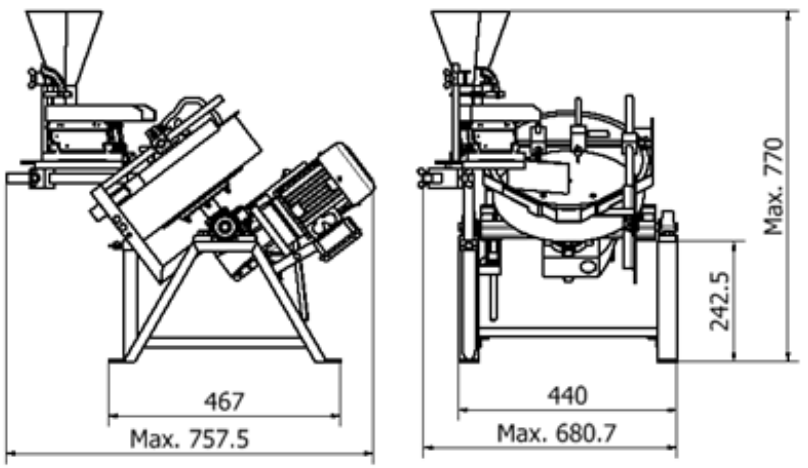

d)

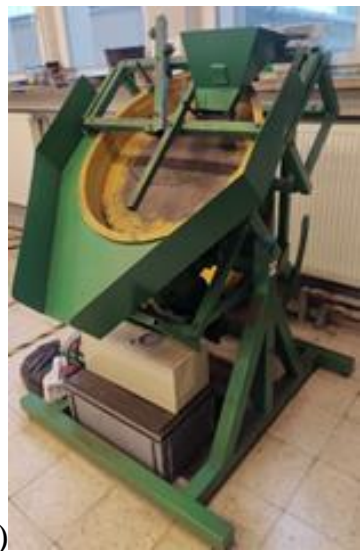

e)
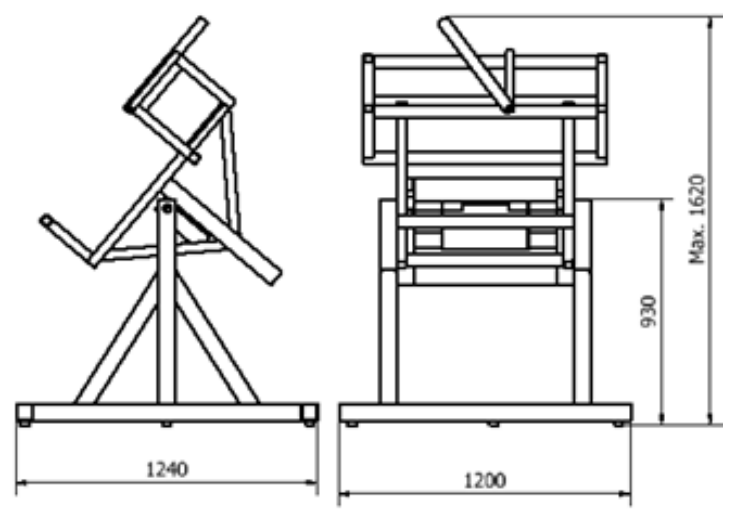

Fig. 1. The model of the disc granulator: a) LDG300 front view, b) LDG300 rear view, c) LDG300 dimensional drawing, d) DG750 view, e) DG750 dimensional drawing. 
Additionally, the rail on which the scraper and the binder dispenser are mounted was loaded by the pressure exerted by the material on the surface of the scraper blade during the working movement. In the place of the supports, mates were placed on the frame elements. For LDG300 model at the point of contact of the spigot with the bearing, non-sliding mates were imposed. The mates block the axial movement in the non-sliding support. In the place of connection of the upper and lower parts of the frame a restraint bond was applied. It simulates the support of the system by a bolt (figures $3 \mathrm{a}$ and $3 \mathrm{~b}$.). Additionally, in the case of the lower frame (figures $3 \mathrm{c}$ and $3 \mathrm{e}$ ) the bottom of the model legs were fixed, which simulates screwing them to the ground. In the case of the DG750 model the bonds imposed on the model elements are the same as described above for the LDG300 model, with the difference that the connection of the upper and lower frame is made of pins, which was simulated by the use of bolted bonds (figure 3d). In both cases the value of loads (figure 4) applied to the lower part of the frame was assumed in accordance with the values of forces and reaction moments occurring in the supports of the upper part of the frame (bearings and the element of the mechanism setting the support angle). The both lower frames were loaded with force and torque from the attached, adjustable granular material dosing system. The frames material parameters are presented in table 3.

The parameters of the mesh superimposed on the analyzed elements are presented in table 4 . After the program generates the mesh models the frame elements look as follows (figure 5).

For such prepared models a stress analysis was performed using the module built into the Autodesk Inventor. In the next part, simulations were carried out to determine the behaviors of the LDG300 and DG750 disc granulators when they are lifted or moved over the surface on which they stand.
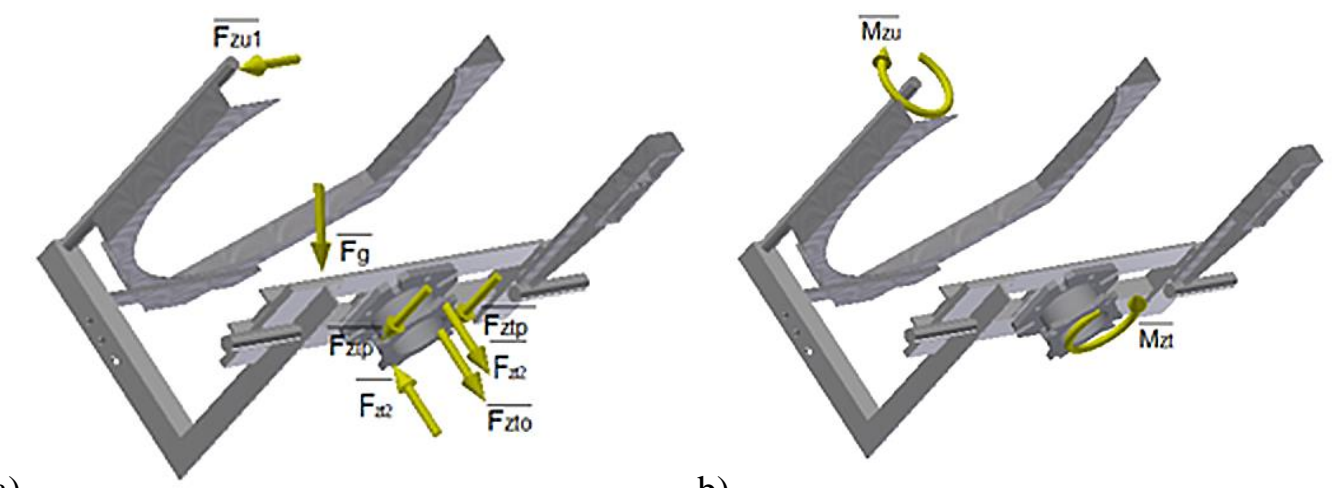

a)

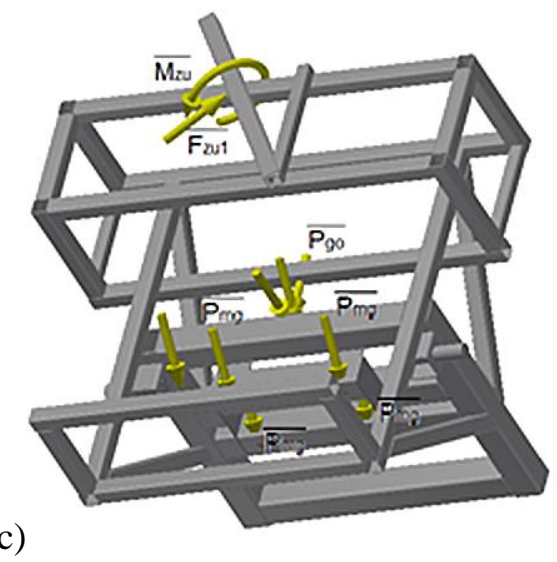

b)

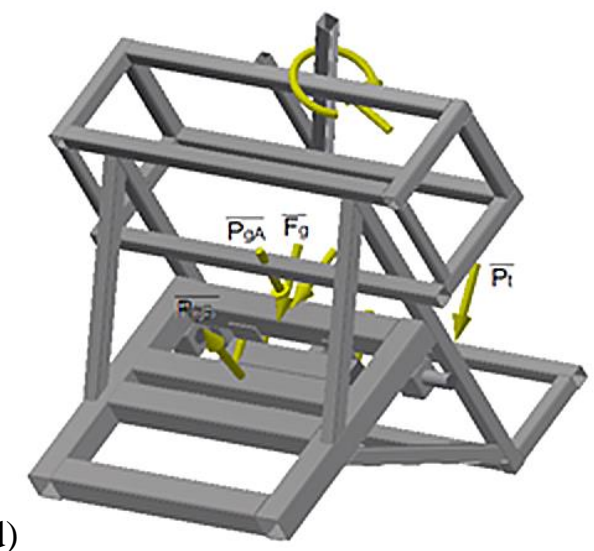

Fig. 2. The loads of the upper part of the frame: a) LDG300 forces, b) LDG300 moments, $c, d)$ DG750 forces and moments. 
a)

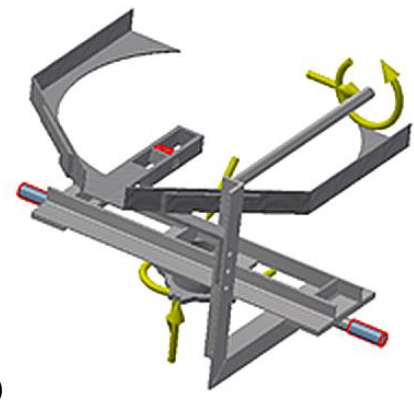

b)

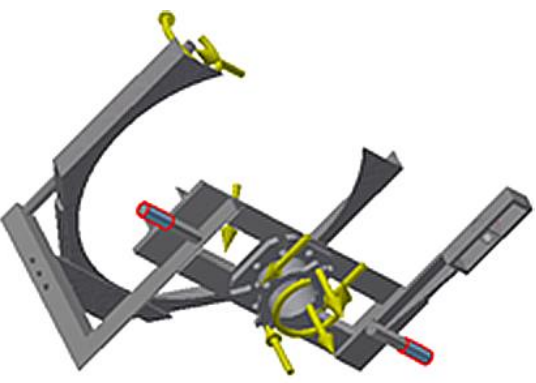

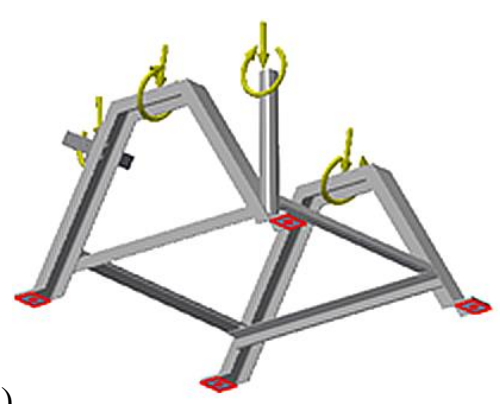

c) d)

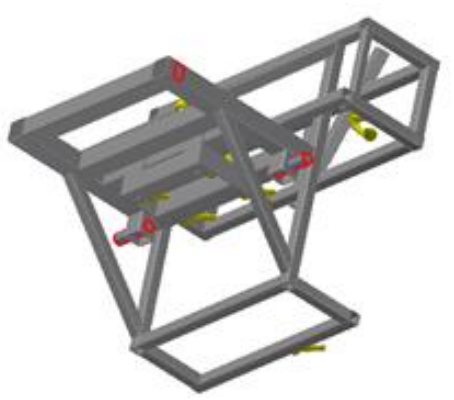

e)

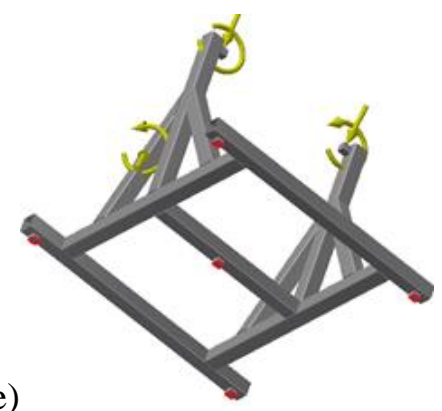

Fig. 3. The place of overlap for: a) LDG300 upper part of the frame, b) LDG300 upper part of the frame - rear view, c) LDG300 lower part of the frame, d) DG750 upper part of the frame, e) DG750 lower part of the frame.

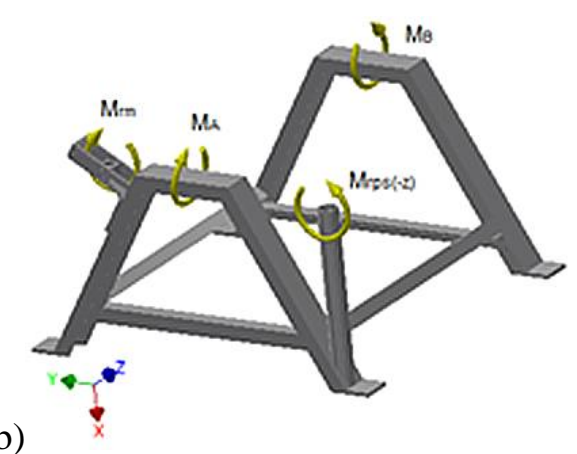

c)

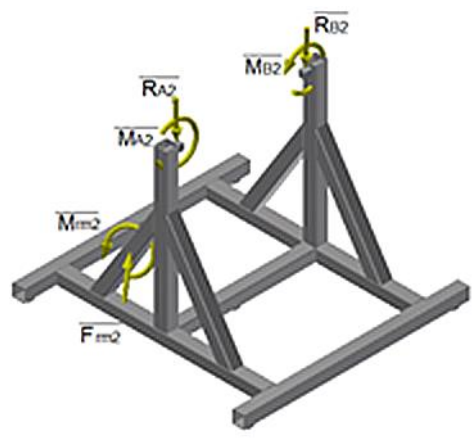

Fig. 4. The loads of the lower part of the frame: a) LDG300 forces, b) LDG300 moments, c) DG750 moments and forces.

Table 2. Influence of the angle of inclination of the axis of the disc granulator on the magnitudes of forces and moments acting on the granulator frame.

\begin{tabular}{|c|c|c|c|c|c|}
\hline \multicolumn{2}{|c|}{} & $\alpha=60^{\circ}$ & $\alpha=50^{\circ}$ & $\alpha=40^{\circ}$ & $\alpha=30^{\circ}$ \\
\hline \multirow{5}{*}{ LDG300 } & $F_{z t o}, \mathrm{~N}$ & 27.7 & 42.8 & 56.4 & 68.7 \\
\cline { 2 - 6 } & $F_{z t p}, \mathrm{~N}$ & 91.6 & 79.8 & 65.7 & 50.7 \\
\cline { 2 - 6 } & $M_{z t}, \mathrm{Nm}$ & 1.1 & 1.4 & 1.6 & 1.8 \\
\cline { 2 - 6 } & $F_{z t 2}, \mathrm{~N}$ & 249 & 236.6 & 218.3 & 197.2 \\
\cline { 2 - 6 } & $M_{z u}, \mathrm{Nm}$ & 1.85 & 1.85 & 1.85 & 1.85 \\
\cline { 2 - 6 } & $F_{z u 1}, \mathrm{~N}$ & 15.4 & 15.4 & 15.4 & 15.4 \\
\cline { 2 - 6 } & $F_{z u 2,}, \mathrm{~N}$ & 11 & 11 & 11 & 11 \\
\hline \multirow{5}{*}{ DG750 } & $P_{t}, \mathrm{~N}$ & 50 & 50 & 50 & 50 \\
\cline { 2 - 6 } & $P_{g A}, \mathrm{~N}$ & 1534.8 & 1973.0 & 2351.3 & 2658.3 \\
\cline { 2 - 6 } & $P_{g B}, \mathrm{~N}$ & 657.8 & 845.6 & 1007.7 & 1139.3 \\
\cline { 2 - 6 } & $P_{m g}, \mathrm{~N}$ & 174.1 & 174.1 & 174.1 & 174.1 \\
\cline { 2 - 6 } & $P_{g o}, \mathrm{~N}$ & 1519 & 1344 & 1127 & 877 \\
\cline { 2 - 6 } & $F_{z u 1}, \mathrm{~N}$ & 57 & 57 & 57 & 57 \\
\cline { 2 - 6 } & $M_{z u}, \mathrm{Nm}$ & 6.6 & 6.6 & 6.6 & 6.6 \\
\hline
\end{tabular}

For the LDG300 granulator model the upper part for the simulation was replaced with a functional model of the bearing housing in which a spherical bearing connected with the shaft simulating the up- per part of the frame was mounted. The bonds and contacts between the individual elements have been selected to simulate the installed bearing system. The bearing-imitating element provides the possibility of rotation of the shaft and the shaft itself can move in the axial direction in relation to the bearing seat in the sliding support, while in the non-sliding support this movement is impossible.

Table 3. Parameters of materials used to design the granulator frame.

\begin{tabular}{|c|c|c|c|c|c|}
\hline \multirow{2}{*}{} & \multicolumn{3}{|c|}{ LDG300 } & \multicolumn{2}{c|}{ DG750 } \\
\cline { 2 - 6 } & $\begin{array}{c}\text { Lower } \\
\text { frame }\end{array}$ & $\begin{array}{c}\text { Upper } \\
\text { frame }\end{array}$ & $\begin{array}{c}\text { Upper } \\
\text { frame - } \\
\text { bearing } \\
\text { pits }\end{array}$ & $\begin{array}{c}\text { Lower } \\
\text { frame }\end{array}$ & $\begin{array}{c}\text { Upper } \\
\text { frame }\end{array}$ \\
\hline Material & S235 JR & S235 JR & E360 & S235 JR & S235 JR \\
\hline$R m, \mathrm{MPa}$ & 340 & 340 & 490 & 340 & 340 \\
\hline$R e, \mathrm{MPa}$ & 235 & 235 & 350 & 235 & 235 \\
\hline$E, \mathrm{GPa}$ & 2.1 & 2.1 & 2.1 & 2.1 & 2.1 \\
\hline$v$ & 0.28 & 0.28 & 0.28 & 0.28 & 0.28 \\
\hline$\rho, \mathrm{g} / \mathrm{cm}^{3}$ & 7.85 & 7.85 & 7.85 & 7.85 & 7.85 \\
\hline
\end{tabular}


Table 4. Characteristic of the mesh sizes.

\begin{tabular}{|c|c|c|c|c|}
\hline & \multicolumn{2}{|c|}{ LDG300 } & \multicolumn{2}{c|}{ DG750 } \\
\cline { 2 - 5 } & $\begin{array}{c}\text { Lower } \\
\text { frame }\end{array}$ & $\begin{array}{c}\text { Upper } \\
\text { frame }\end{array}$ & $\begin{array}{c}\text { Lower } \\
\text { frame }\end{array}$ & $\begin{array}{c}\text { Upper } \\
\text { frame }\end{array}$ \\
\hline $\begin{array}{c}\text { Average element } \\
\text { size - the fractional } \\
\text { length of the } \\
\text { bounding box }\end{array}$ & 0.1 & 0.1 & 0.1 & 0.1 \\
\hline $\begin{array}{c}\text { Minimum element } \\
\text { size - fraction of } \\
\text { the average size }\end{array}$ & 0.2 & 0.2 & 0.2 & 0.2 \\
\hline Graduation factor & 1.5 & 1.5 & 1.5 & 1.5 \\
\hline $\begin{array}{c}\text { Maximum angle of } \\
\text { the grid triangle, }\end{array}$ & 60 & 60 & 60 & 60 \\
\hline Number of nodes & 59949 & 87564 & 150562 & 199938 \\
\hline
\end{tabular}

a)

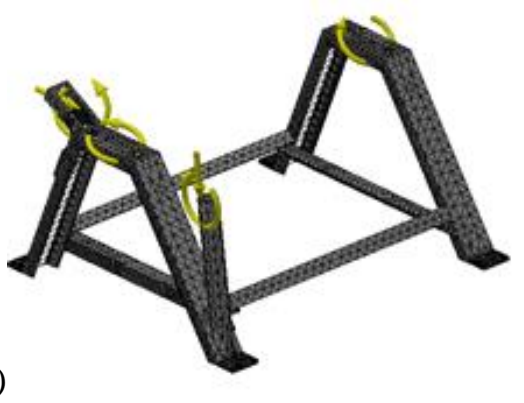

b)

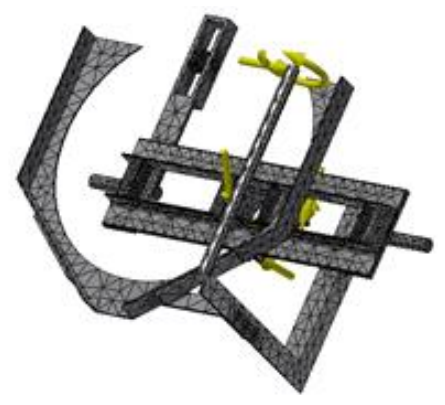

Fig. 5. The view of the grid: a) LDG300 lower frame, b) LDG300 upper frame, c) DG750 lower frame, d) DG750 upper frame.
For the DG750 the upper frame has been replaced by a shaft embedded in the holes that normally contain the pins connecting the upper and lower frames. The bonds and contacts between the individual elements have been selected to simulate the possibility of rotation of the upper frame in relation to the lower frame, taking into account the possibility of a slight movement of the elements in relation to each other due to the presence of a loose fit between them. The constructed models (figures 6 and 7) were loaded with forces and moments originating from the construction elements of the granulator as well as the material contained in it. The simulations carried out aimed to reproduce the case of maximum load of the granulators. The coefficient of friction $\mu$ $=0.85$ was used as the frictional connections between the ground elements and the frame legs. It was assumed for the purposes of the calculations that the rubberized legs of the granulators can be moved over the concrete surface, which generates considerable resistance. For the consideration of displacement of the granulator the two variants force applying were envisaged in the case of the LDG300 granulator (figures $7 \mathrm{a}$ and $7 \mathrm{~b}$ ) and one case of applying force to the frame of the DG750 granulator due to its symmetrical structure (figure $7 \mathrm{c}$ ). The values of the applied forces and moments are shown in table 5 .

Table 5. The influence of the type of load on the forces and moments acting on the frame.

\begin{tabular}{|c|c|c|c|}
\hline $\begin{array}{c}\text { Case } \\
\text { Value }\end{array}$ & $\begin{array}{c}\text { The frame } \\
\text { moved by the } \\
\text { force applied } \\
\text { to its right side }\end{array}$ & $\begin{array}{c}\text { The frame } \\
\text { moved by the } \\
\text { force applied } \\
\text { to its left side }\end{array}$ & Lifting \\
\hline$F_{r p s s}, \mathrm{~N}$ & 141 & 141 & 141 \\
\hline$M_{r p s(-z), \mathrm{Nmm}}$ & 27 & 27 & 27 \\
\hline$R_{t}, \mathrm{~N}$ & 397 & 397 & 0 \\
\hline$R_{A 2}, \mathrm{~N}$ & 162.4 & 162.4 & 162.4 \\
\hline$R_{B 2}, \mathrm{~N}$ & 162.4 & 162.4 & 162.4 \\
\hline$F_{R A}=F_{R A 2}, \mathrm{~N}$ & - & 1704.5 & 1704.5 \\
\hline$F_{R B}=F_{R B 2}, \mathrm{~N}$ & - & 1704.5 & 1704.5 \\
\hline$F_{t}, \mathrm{~N}$ & - & 3577 & 0 \\
\hline
\end{tabular}

The places and nature of bonds of individual elements were determined for the models.

For the simulation carried out for moving the granulator, pin and frictionless bonds were used (figure 8). They provide a simulation of the granulator moving on a flat surface without the possibility of breaking away from it. 
a)
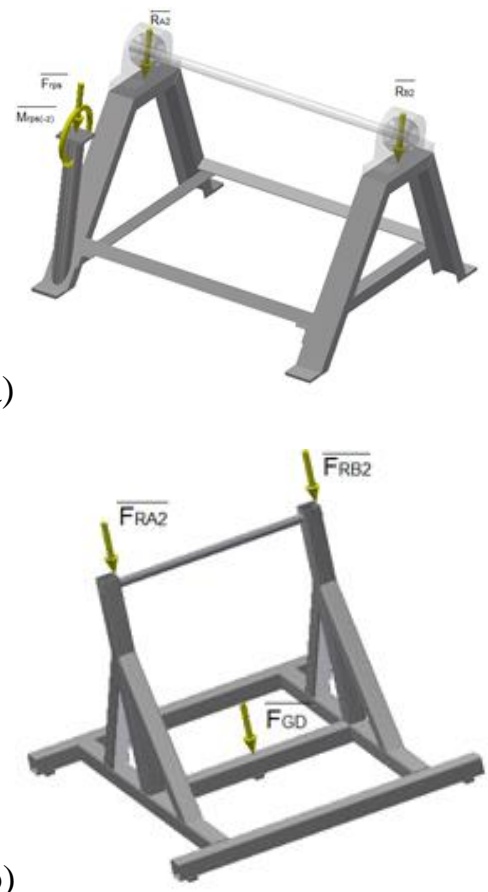

Fig. 6. The view of the loads putting to the frame in the lifting case of model: a) LDG300, b) DG750.

a)

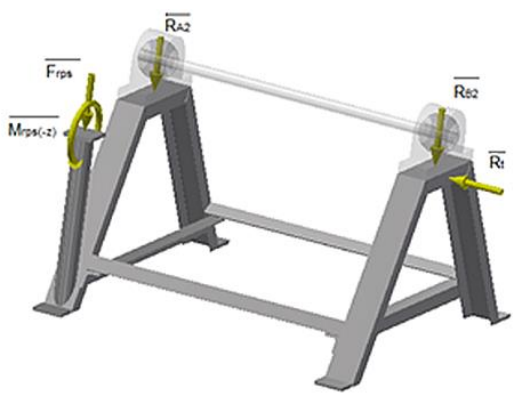

b)
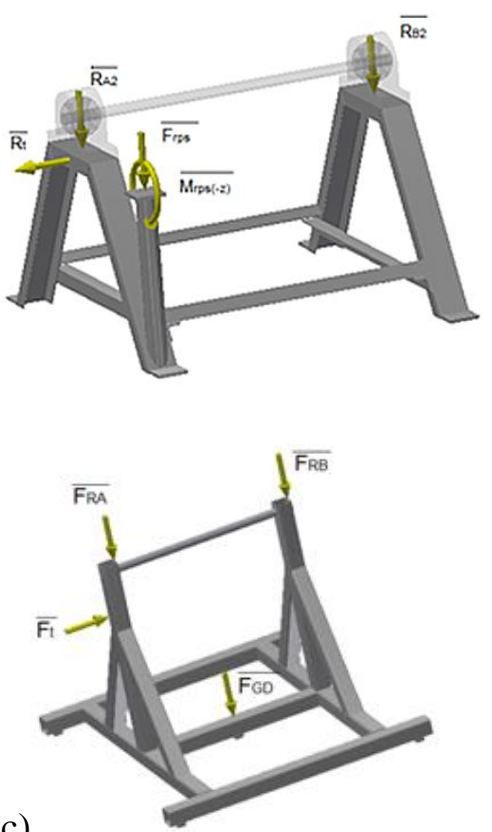

Fig. 7. The model of frame sliding frame with the force applied to: a) LDG300 right part of the frame, b) LDG300 left part of the frame, c) model of DG750 granulator.

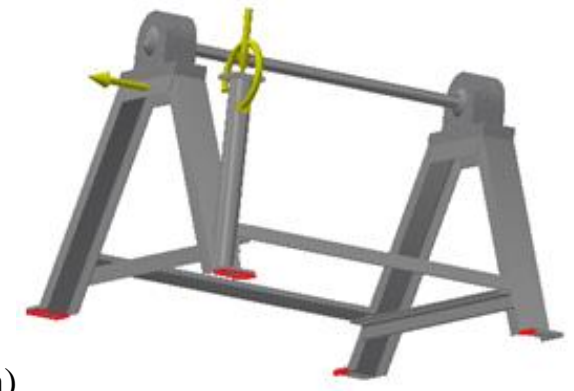

a)

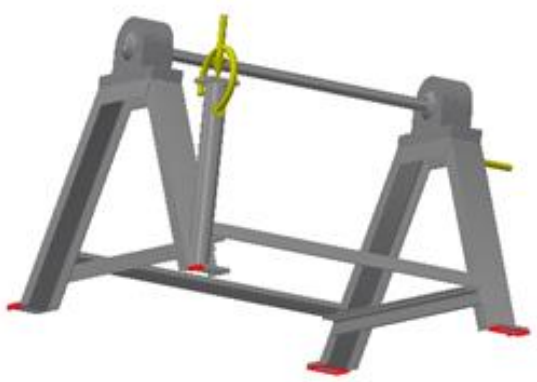

b)

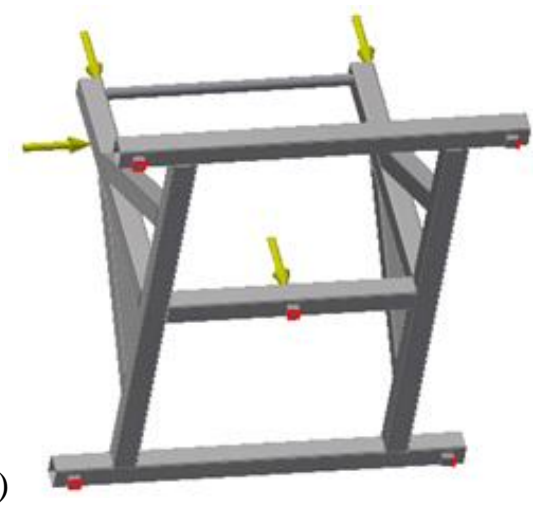

Fig. 8. Accepted places of application of the supports of the sliding frame with the force applied to: a) right (LDG300), b) left support (LDG300), c) model of DG750 granulator.

Moreover, the pin-type bonding, which was applied to the base element on the opposite side of loads allows to catch the moment when the element is not yet sliding across the surface but may deviate from the vertical. In the case of lifting/carrying the granulator, two areas with a width corresponding to the width of human hand were marked on the frame elements of the LDG300 granulator (figure 9a), and four areas with the width of the transport belt were marked on the frame elements of the DG750 frame, which simulate the places of the granulator's grip (figure 9b). In both cases, half of marked areas were fixed giving one half a bond corresponding to the non-pushed support and the other half corresponding to the sliding support (figure 10). For such prepared models a mesh was generated (table 6). To perform the simulation the remaining parameters were adopted with the values consistent with the parameters adopted for the simulation of the lower frame loads, which were presented above. 


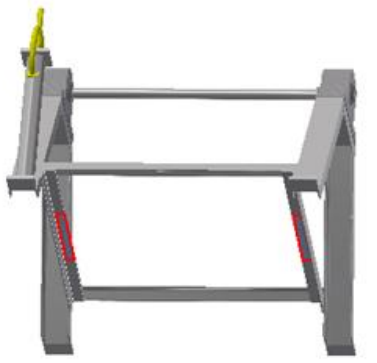

a)

b)

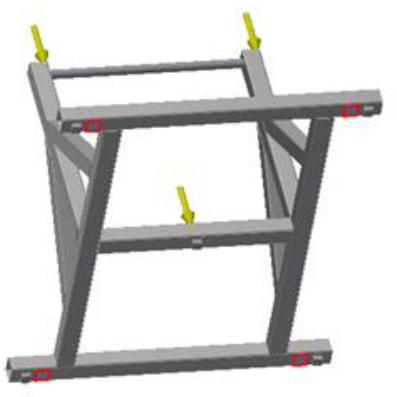

Fig. 9. The places of application of the lifted frame supports in: a) model LDG300, b) model DG750.

a)
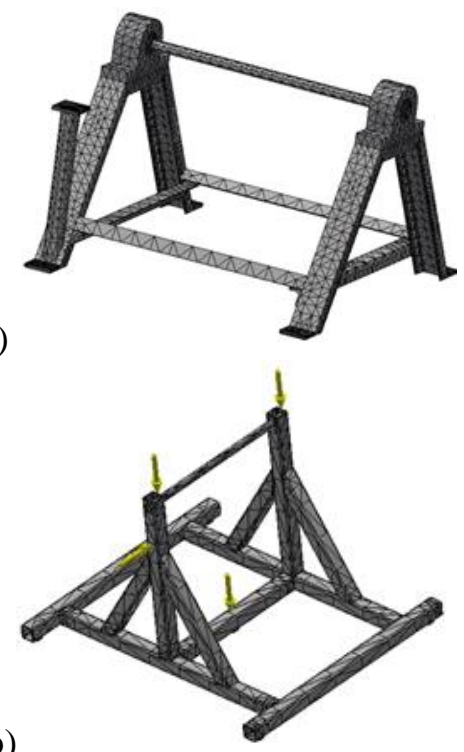

b)

Fig. 10. The view of the grid superimposed on the model: a) $L D G 300, b) D G 750$.

Table 6. Characteristic of the mesh sizes.

\begin{tabular}{|c|c|c|}
\hline & LDG300 & DG750 \\
\hline $\begin{array}{c}\text { Average element size (as the frac- } \\
\text { tional length of the bounding box) }\end{array}$ & 0.1 & 0.1 \\
\hline $\begin{array}{c}\text { Minimum element size (as a fraction } \\
\text { of the average size) }\end{array}$ & 0.2 & 0.2 \\
\hline Graduation factor $^{\text {Maximum angle of the grid triangle }}{ }^{\circ}$ & 1.5 & 1.5 \\
\hline Number of nodes & 89414 & 60 \\
\hline Power of the motor, $\mathrm{kW}$ & 0.18 & 3.0 \\
\hline
\end{tabular}

\section{RESULTS AND DISCUSSION}

Based on the analyses of the upper part of the frame (table 7) it can be seen that the small- est angle of inclination of the axis of the LDG300 granulator disc causes the lowest reduced stresses in accordance to the HuberMises-Hencky (HMH) hypothesis. The greatest stresses are observed for the $60^{\circ}$ angle. The same applies to the values of the maximum displacements occurring in the model. It is worth noting that the value of the maximum stresses for the largest angle is over $18.4 \%$ greater than the maximum stresses observed for the smallest one (figure 11). The displacement observed for the $60^{\circ}$ angle is around $13 \%$ greater than the displacement generated in the simulation carried out for the $30^{\circ}$ angle (figure 12). As can be seen in figure 11 an increase of the angle of inclination increases the value of stresses and the growth of zones of increased stresses in relation to the stresses in the vicinity. As for the stresses transferred by the lower part of the frame the difference between the maximum reduced stresses for individual angles of the disc axis inclination does not exceed $8.9 \%$ of the lowest value presented in table 8 . As shown in figure 13, the locations of increased stresses in the model do not depend on the working angle of the granulator disc.

Table 7. Parameters of materials used to design the granulator frame.

\begin{tabular}{|c|c|c|c|c|c|}
\hline \multicolumn{2}{|c|}{} & $60^{\circ}$ & $50^{\circ}$ & $40^{\circ}$ & $30^{\circ}$ \\
\hline \multirow{2}{*}{ LDG300 } & $\begin{array}{c}\text { Max. stress } \\
\text { HMH, MPa }\end{array}$ & 57.51 & 50.83 & 54.19 & 46.90 \\
\cline { 2 - 6 } & $\begin{array}{c}\text { Max. displace- } \\
\text { ment, mm }\end{array}$ & 2.43 & 2.40 & 2.36 & 2.12 \\
\hline \multirow{2}{*}{ DG750 } & $\begin{array}{c}\text { Max. stress } \\
\text { HMH, MPa }\end{array}$ & 87.68 & 95.14 & 93.88 & 95.91 \\
\cline { 2 - 6 } & $\begin{array}{c}\text { Max. displace- } \\
\text { ment, mm }\end{array}$ & 0.06 & 0.06 & 0.09 & 0.09 \\
\hline
\end{tabular}

Table 8. The simulation results for the lower part of the frame.

\begin{tabular}{|c|c|c|c|c|c|}
\hline \multicolumn{2}{|c|}{} & $60^{\circ}$ & $50^{\circ}$ & $40^{\circ}$ & $30^{\circ}$ \\
\hline \multirow{2}{*}{ LDG300 } & $\begin{array}{c}\text { Max. stress } \\
\text { HMH, MPa }\end{array}$ & 44.21 & 46.58 & 43.19 & 42.77 \\
\cline { 2 - 6 } & $\begin{array}{c}\text { Max. displace- } \\
\text { ment, mm }\end{array}$ & 0.28 & 0.28 & 0.28 & 0.29 \\
\hline \multirow{2}{*}{ DG750 } & $\begin{array}{c}\text { Max. stress } \\
\text { HMH, MPa }\end{array}$ & 39.88 & 40.77 & 44.82 & 43.43 \\
\cline { 2 - 6 } & $\begin{array}{c}\text { Max. displace- } \\
\text { ment, mm }\end{array}$ & 0.57 & 0.54 & 0.42 & 0.55 \\
\hline
\end{tabular}

The situation is different for the DG750 granulator, because the higher stress values are observed for smaller values of the plate axis inclination angle. The highest value of $\mathrm{HMH}$ stresses is observed for the angle of $30^{\circ}$ (figure 11). The difference between the highest and the 

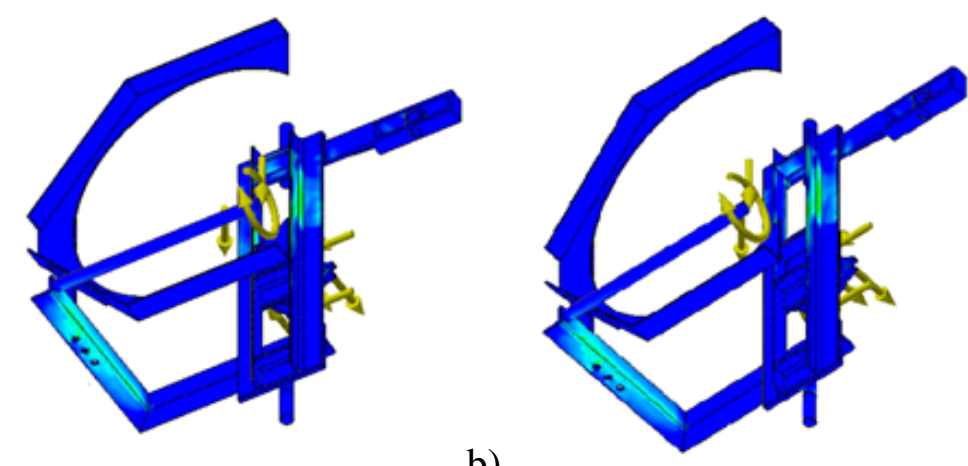

a)

b)

c)

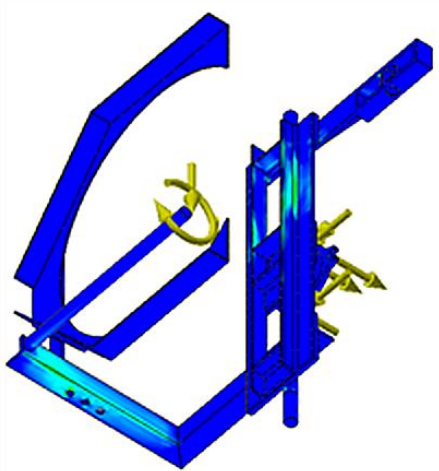

d)
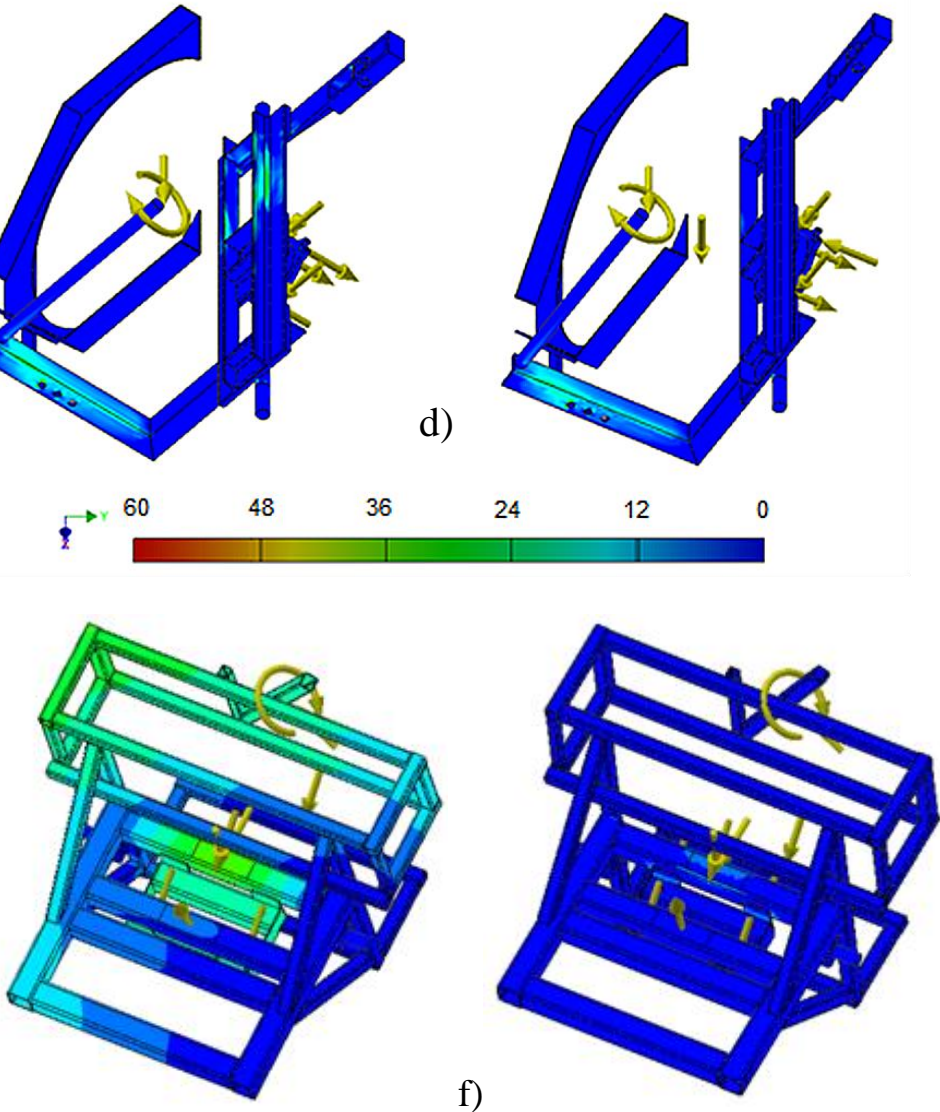

e)

f)
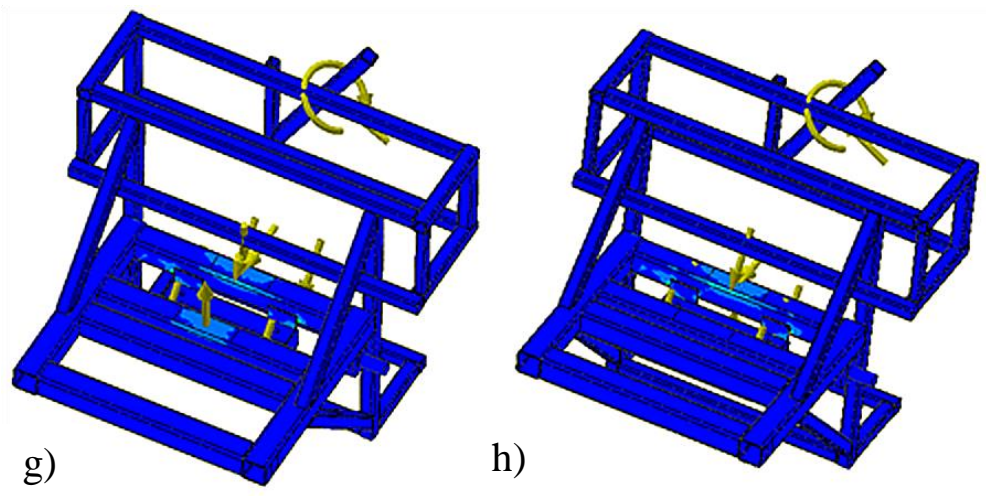

h)

Fig. 11. The stress diagram (in MPa) for LDG300 granulator's upper frame and the plate axis inclination angle equal to: a) $60^{\circ}$, b) $50^{\circ}$, c) $40^{\circ}$, d) $30^{\circ}$, and DG750 granulator's upper frame and the plate axis inclination angle equal to: e) $\left.60^{\circ}, f\right) 50^{\circ}$, g) $40^{\circ}$, h) $30^{\circ}$. 


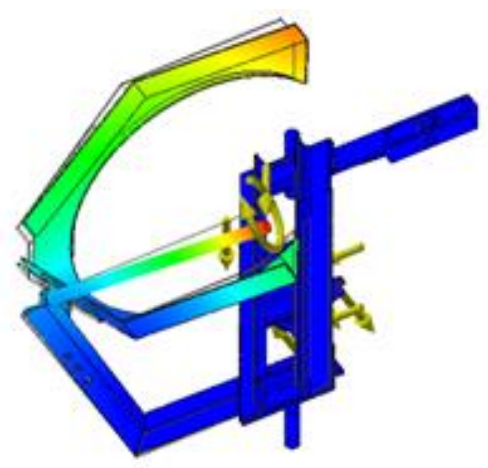

a)

c)

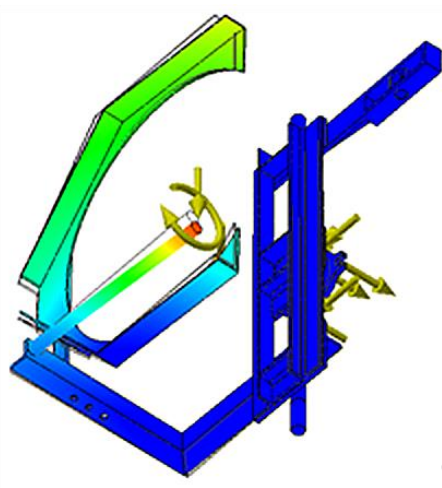

d)

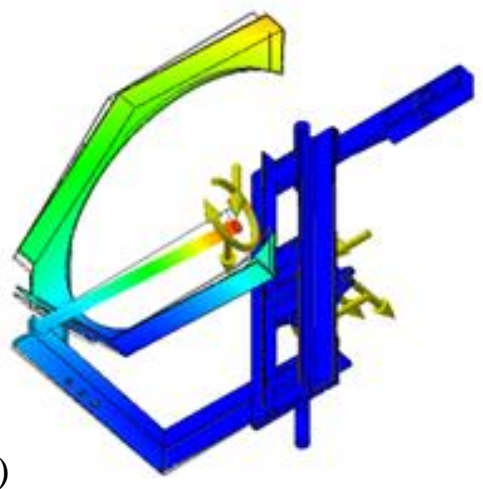

b)
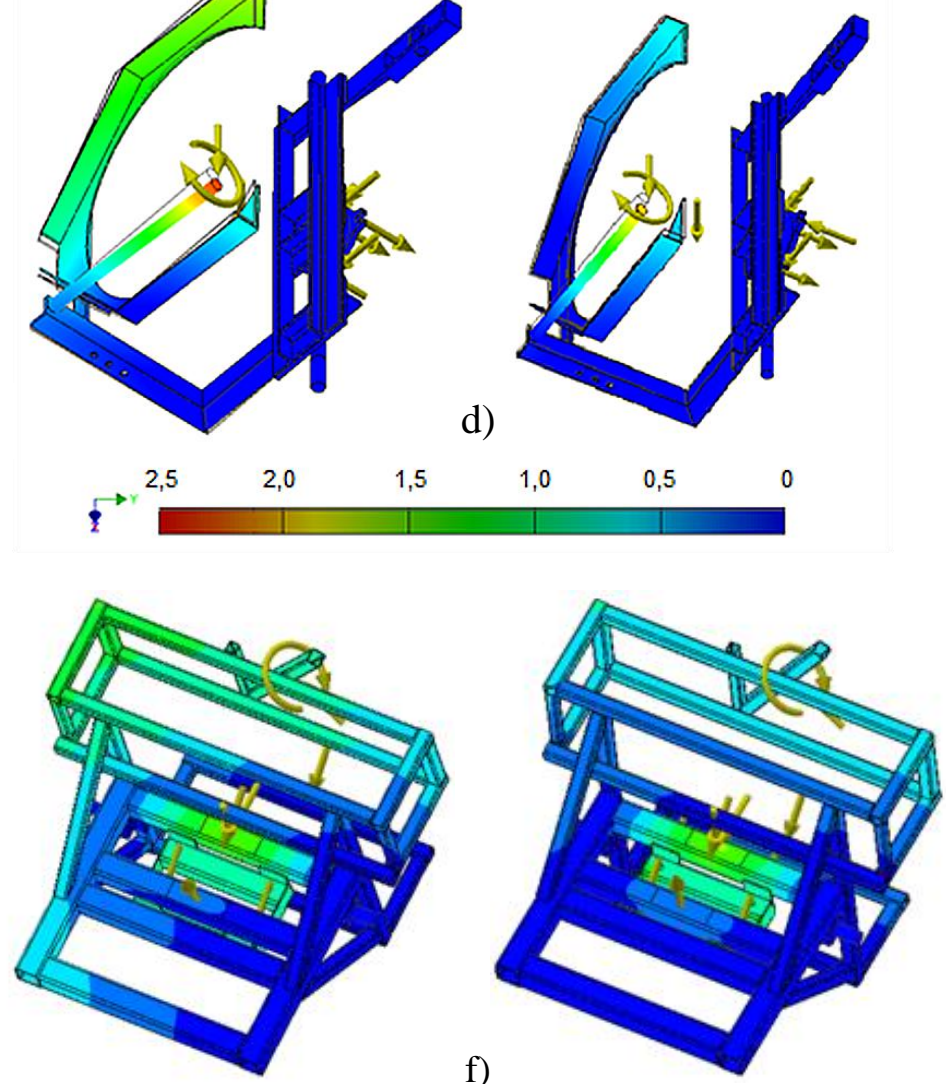

e)

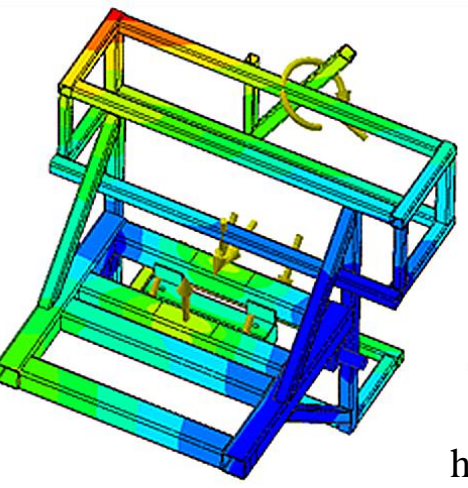

h)

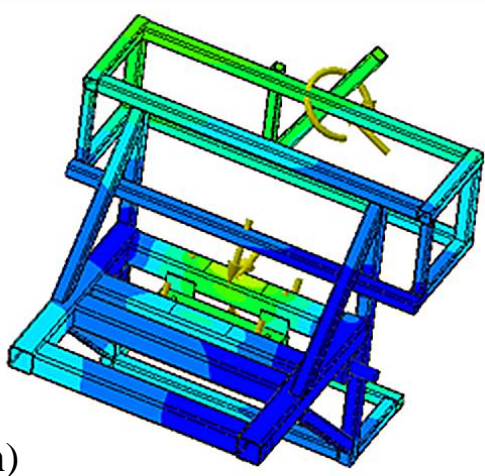

$\begin{array}{lllllllllll}0,1 & 0,09 & 0,08 & 0,07 & 0,06 & 0,05 & 0,04 & 0,03 & 0,02 & 0,01 & 0\end{array}$

Fig. 12. The displacements diagram (in $\mathrm{mm}$ ) for LDG300 granulator's upper frame and the plate axis inclination angle equal to: a) $60^{\circ}$, b) $50^{\circ}$, c) $40^{\circ}$, d) $30^{\circ}$, and DG750 granulator's upper frame and the plate axis inclination angle equal to: e) $\left.60^{\circ}, f\right) 50^{\circ}$, g) $40^{\circ}$, h) $30^{\circ}$. 
a)
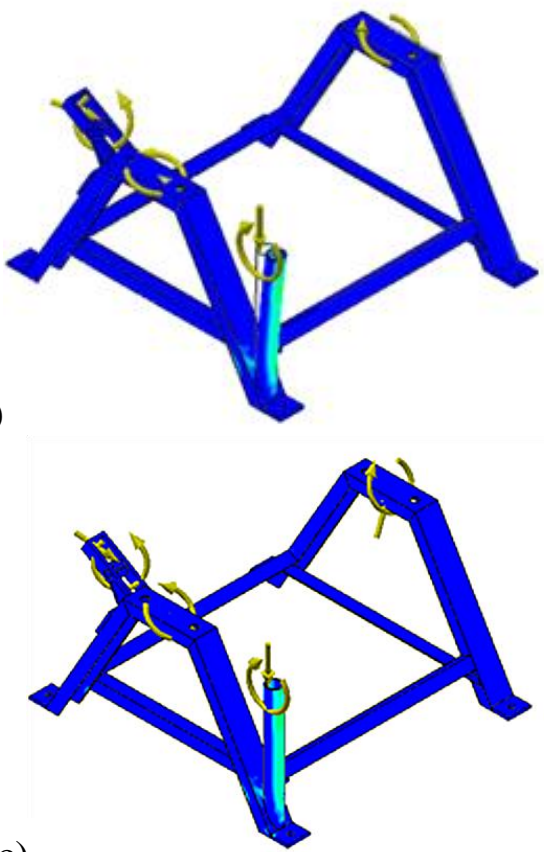

c)

e)

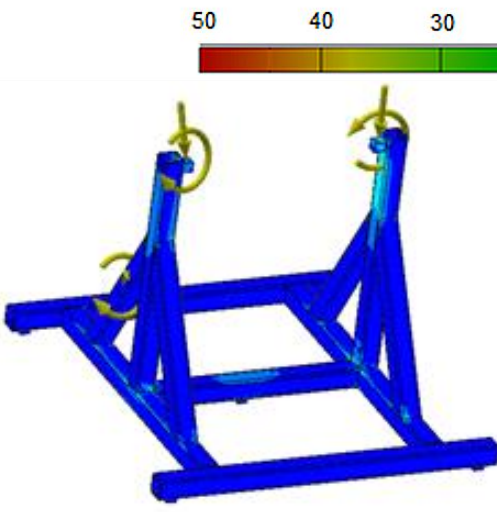

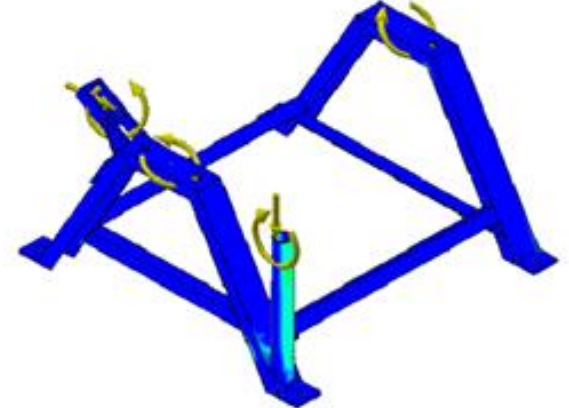

b)

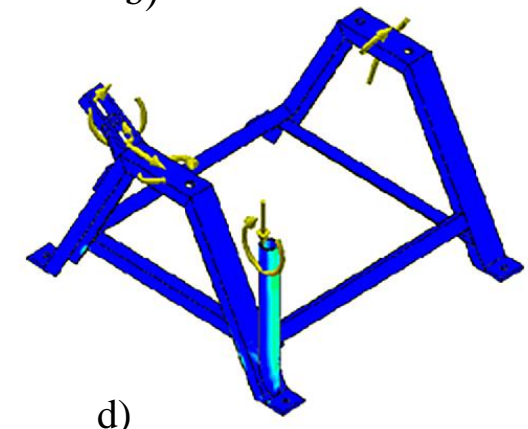

d)

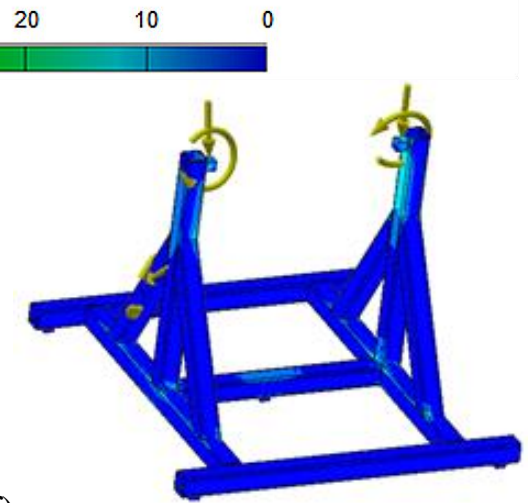

Fig. 13. The stress diagram (in MPa) for LDG300 granulator's lower frame and the plate axis inclination angle equal to: a) $60^{\circ}$, b) $50^{\circ}$, c) $40^{\circ}$, d) $30^{\circ}$, and DG750 granulator's upper frame and the plate axis inclination angle equal to: e) $\left.\left.\left.60^{\circ}, f\right) 50^{\circ}, g\right) 40^{\circ}, h\right) 30^{\circ}$.

lowest stresses does not exceed $9 \%$ of the value of the highest maximum stress (table 7). Similarly, the maximum values of displacement are maintained, for which for the values of $30^{\circ}$ and $40^{\circ}$ of the inclination of the granulator axis, greater values are noted than for $50^{\circ}$ and $60^{\circ}$ (figure 12). The same applies to the maximum stresses appearing in the lower part of the frame for which higher stress values were obtained for smaller angles of the disc axis (figure 13). The stress difference between the extreme maximum stresses is $11 \%$. In the case of displacements of the elements of the lower frame of the DG750 granulator, the bigger displacement was observed for the angle of $60^{\circ}$ and the lowest for the angle of $40^{\circ}$ (table 8). The locations of increased stresses in the model (figure 13) do not depend on the working angle of the granulator disc.Their size in the lower part of the granulator differs slightly and the differ- ence in stress between individual cases is small. The highest stress value for the LDG300 granulator model was obtained for the angle of $50^{\circ}$ and the lowest for the angle of $30^{\circ}$. The highest stress is placed at the point of connecting the element responsible for mounting the adjustable arm under the bulk material dispenser with the rest of the frame. For the DG750 granulator model, the highest stress values were obtained for the angle of $30^{\circ}$ and the lowest for the angle of $60^{\circ}$. The greatest stresses occurred at the connection of the table on which the gearmotor is mounted with the rest of the frame.

The displacements of LDG300 are shown in figures $14 \mathrm{a}$-d. The difference between the largest and the smallest maximum displacement does not exceed $3.5 \%$ in this case. For angles of $60^{\circ}, 50^{\circ}, 40^{\circ}$ the value of the greatest displacement of the frame element is the same. It should be noted that the tested 
a)
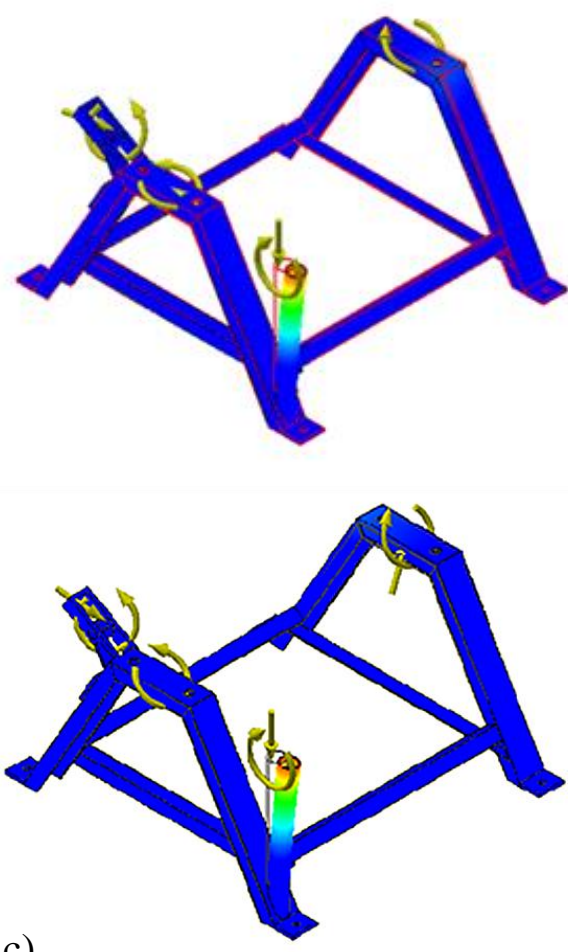

c)

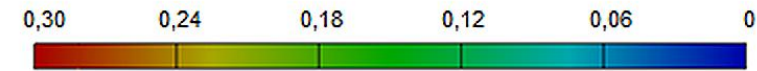

e)

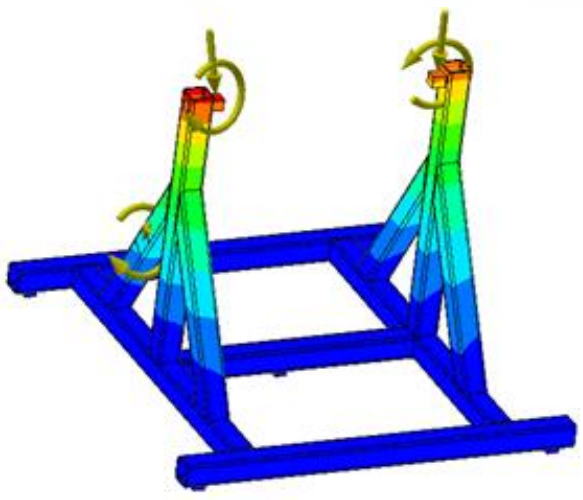

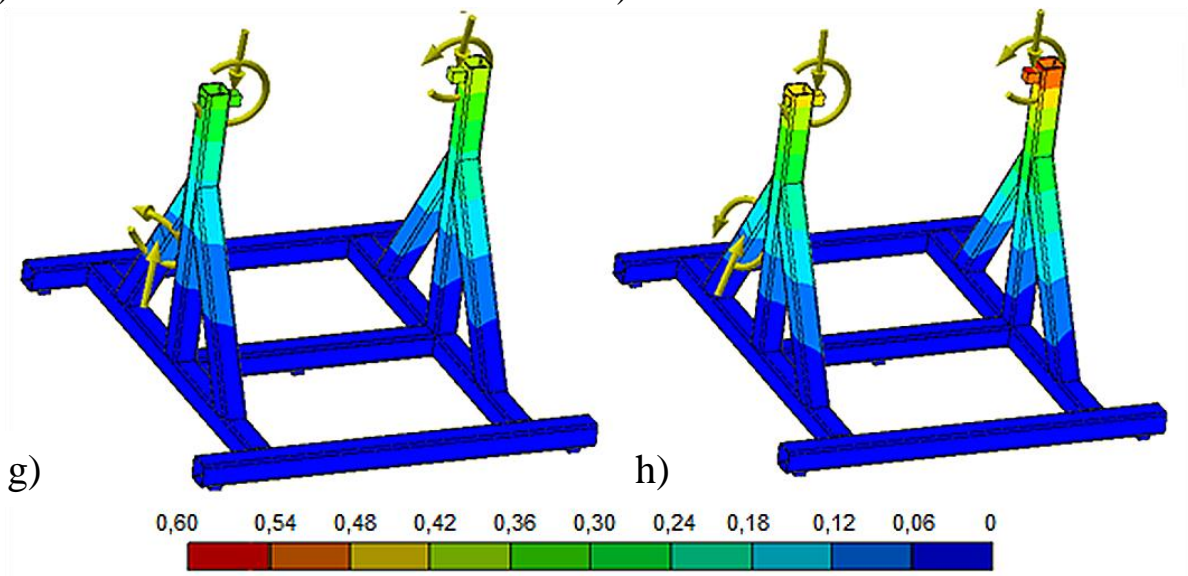

b)

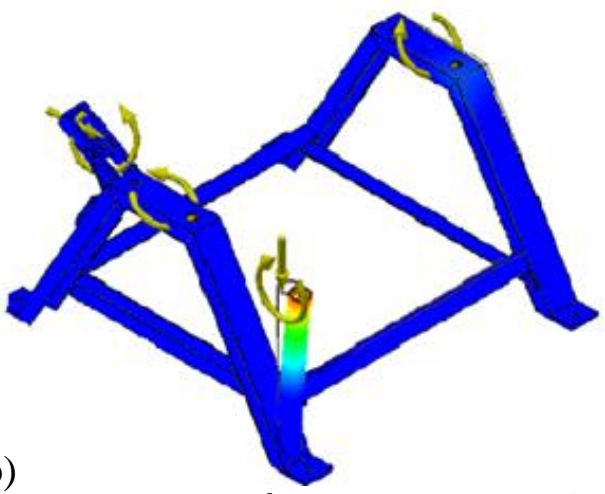

d)
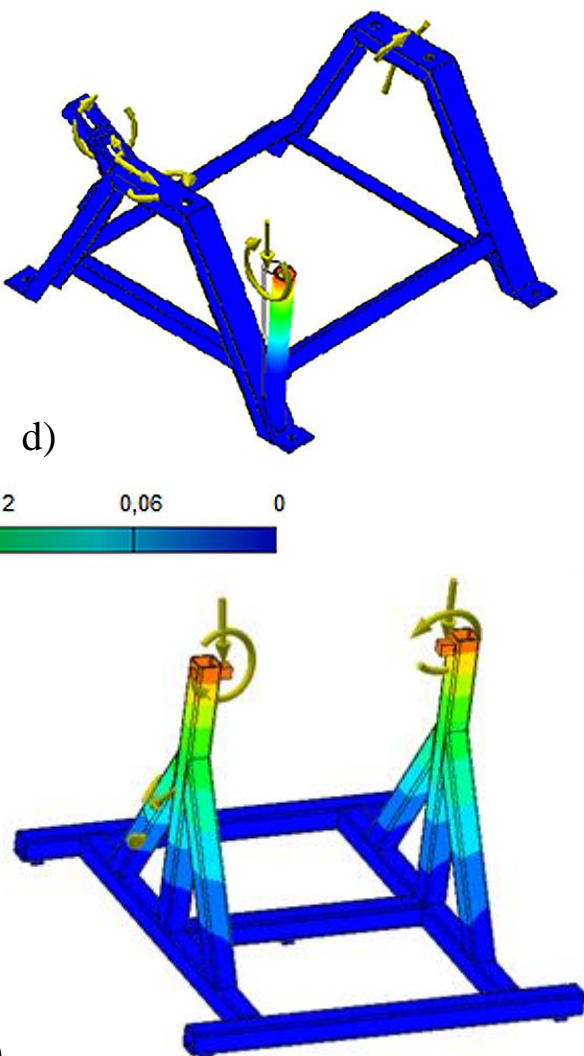

f)

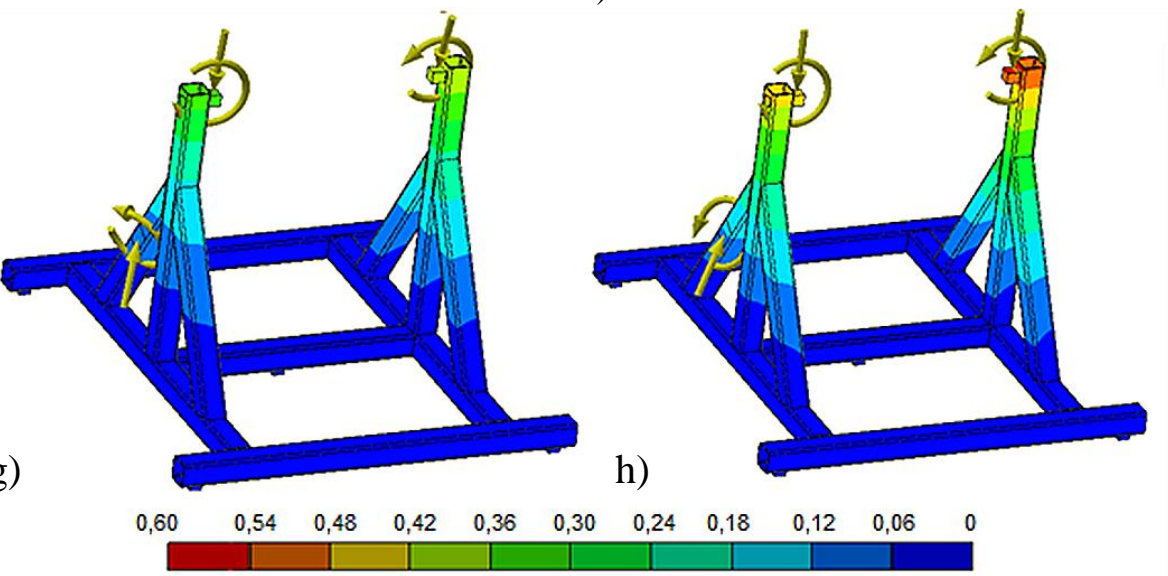

Fig. 14. The diagram of displacements (in $\mathrm{mm}$ ) for LDG300 granulator's lower frame and the plate axis inclination angle equal to: a) $60^{\circ}$, b) $50^{\circ}$, c) $40^{\circ}$, d) $30^{\circ}$, and DG750 granulator's upper frame and the plate axis inclination angle equal to: e) $\left.60^{\circ}, f\right) 50^{\circ}$, g) $40^{\circ}, h$ ) $30^{\circ}$.

displacement is the greatest for the element responsible for mounting the arm under the dispenser. The displacements of the remaining elements are much smaller and do not exceed $0.06 \mathrm{~mm}$. The largest displacements occur for the top part of the bearing housing (which is not the direct object of the simula- 
tions) and results from the deflection of the entire part of the support on which it is mounted (figures $15 \mathrm{a}$ and $15 \mathrm{~b}$ ). This is the reason why the values of the displacements in table 8 are approximate for the base of the bearing housing - the surface on which it is mounted to the frame. According to figure 15a and $15 \mathrm{~b}$, they can reach a value of approximately $0.93 \mathrm{~mm}$ for the force applied to the right support and approximately $0.8 \mathrm{~mm}$ for the force applied to the left support. The displacements of the granulator DG750 model according to figure 14c, do not exceed $0.6 \mathrm{~mm}$. The greatest displacements are observed for the top of the element connecting the upper frame with the lower frame. The greatest maximum displacement was recorded for $60^{\circ}$ and it is $0.57 \mathrm{~mm}$, the smallest $0.42 \mathrm{~mm}$ for angle $40^{\circ}$.

As for the results of stresses obtained for the simulation of moving the LDG300 granulator, there is a noticeable difference in the size of the obtained results depending on the place of force application. A higher value of stresses was obtained in the case of applying a force on the right support (figures 16a and 16b). These stresses are $8 \%$ higher than in the case of applying the force on the left side of the frame. The place of maximum stresses also changes as shown in figure 16. The stresses occurring during the transfer of the granulator was $73.97 \mathrm{MPa}$. The displacements of individual elements of the granulator structure reach a value of up to $0.47 \mathrm{~mm}$, with the proviso that this value mainly applies to bearing housings, as was noted in the case of moving the granulator (figures $15 \mathrm{a}$ and $15 \mathrm{~b}$ ). As the structure of the model of the lower frame of the DG750 granulator is symmetrical and the adopted method of its loading does not depend on the adopted geometry, one simulation was carried out showing the sliding of the above frame on the ground (figure 16c). As a result of this simulation, information on the maximum stresses in the frame was obtained, amounting to $109.8 \mathrm{MPa}$. In the case of the displacements shown in figure $16 \mathrm{c}$ the maximum value of the displacements of the frame elements was recorded, amounting to $1.84 \mathrm{~mm}$. In the case of lifting the frame of the DG750 granulator, the stresses obtained from the simulation did not exceed $14 \mathrm{MPa}$ (figure $17 \mathrm{c})$ and the displacements reached the maximum value of $0.07 \mathrm{~mm}$ (figure 18c). In the case of the analysis of lifting the frame of the LDG300 granulator, the value of the maximum stresses reached the value of $73.97 \mathrm{MPa}$ (figure 17a) and the value of the maximum displacements of the frame elements
$0.41 \mathrm{~mm}$ (figure 18a). The values of the results obtained for both models in the case of simulating their sliding and lifting are presented in table 9 .

Table 9. The values obtained from the simulation of shifting and lifting frames.

\begin{tabular}{|c|c|c|c|c|}
\hline \multicolumn{2}{|c|}{} & $\begin{array}{c}\text { Shifting } \\
\text { by force } \\
\text { from the } \\
\text { right }\end{array}$ & $\begin{array}{c}\text { Shifting } \\
\text { by force } \\
\text { from the } \\
\text { left }\end{array}$ & $\begin{array}{c}\text { Frame } \\
\text { lifting }\end{array}$ \\
\hline \multirow{2}{*}{ LDG300 } & $\begin{array}{c}\text { Max. stress } \\
\text { HMH, MPa }\end{array}$ & 134.6 & 124.4 & 73.97 \\
\cline { 2 - 5 } & $\begin{array}{c}\text { Max. displace- } \\
\text { ment, mm }\end{array}$ & 0.8 & 0.93 & 0.27 \\
\hline \multirow{2}{*}{ DG750 } & $\begin{array}{c}\text { Max. stress } \\
\text { HMH, MPa }\end{array}$ & - & 109.8 & 13.71 \\
\cline { 2 - 5 } & $\begin{array}{c}\text { Max. displace- } \\
\text { ment, mm }\end{array}$ & - & 1.84 & 0.07 \\
\hline
\end{tabular}
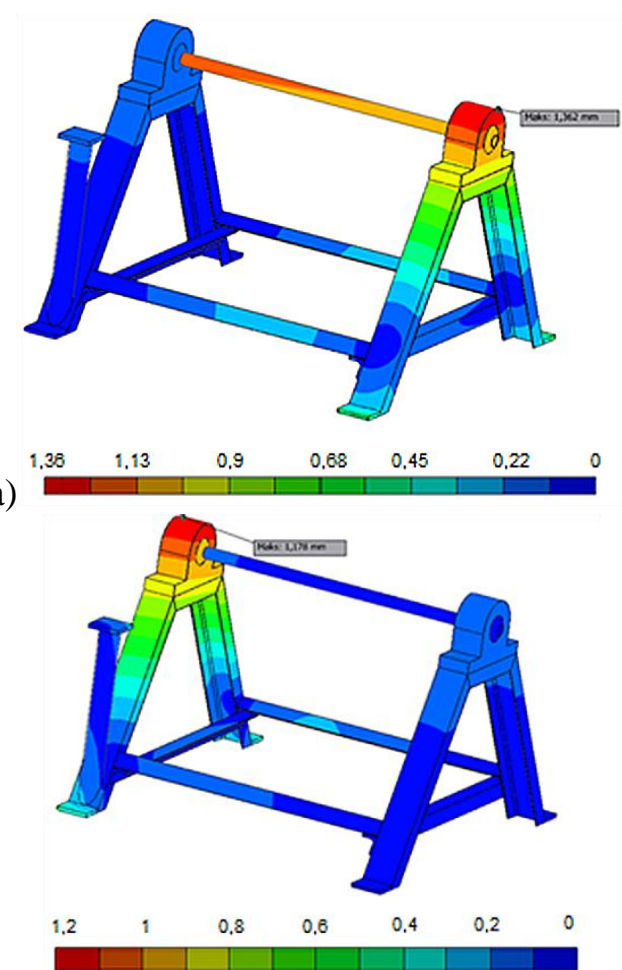

b)

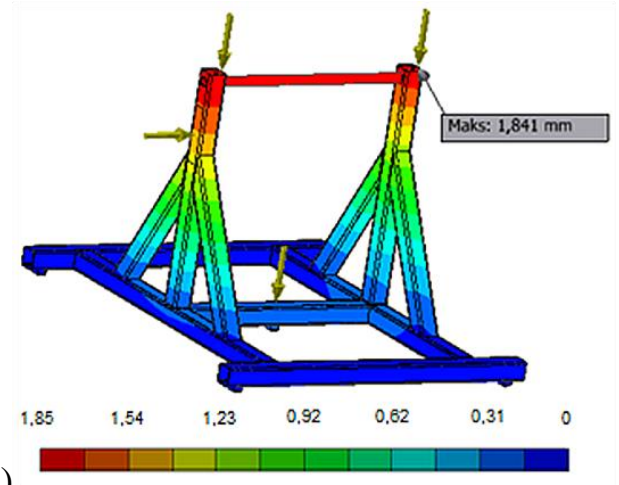

c)

Fig. 15. The diagram of displacements (in $\mathrm{mm}$ ) with the force applied to: a) right support of LDG300 granulator, b) left support of LDG300 granulator, c) model of DG750 granulator. 
a)
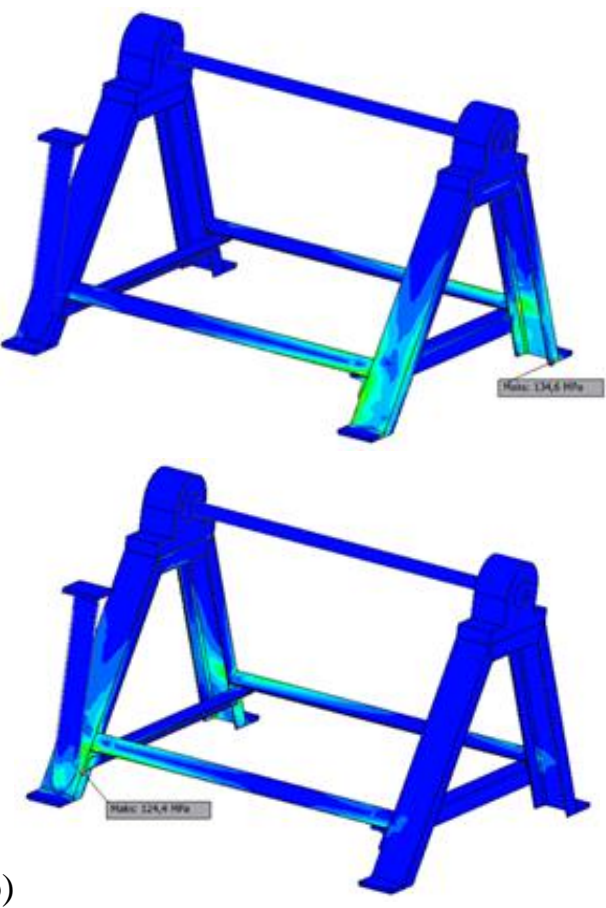

b)

c)

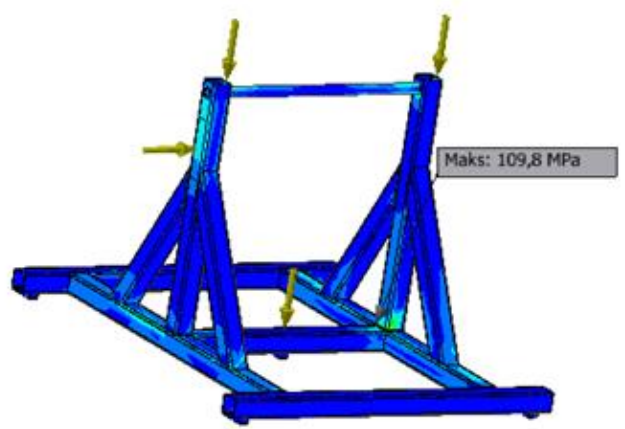

Fig. 16. The diagram of stresses (in MPa) with the force applied to: a) right support of LDG300, b) left support of LDG300, c) model of DG750 granulator.

\section{CONCLUSIONS}

Based on the simulation results, it can be concluded that in the case of the LDG300 and DG750 granulator frame it is reasonable to analyze their upper and lower parts as independent of each other. This procedure allows to limit the number of simulations performed. Observing the obtained results for the lower frame, it can be concluded that the results do not differ significantly from each other. The calculated differences between the obtained results did not exceed $13 \%$ of the value of the smallest stress among the maximum stresses obtained for each simulation. Similar displacement results were obtained, where their values did not differ much from each other. In the analysis of the upper part of the LDG300 granulator frame, higher stress values were obtained for higher values of the angle of inclination of the plate axis, while in the case of the DG750 granulator, this relationship is reversed. It was noted that the increase in stress with increasing angle is not
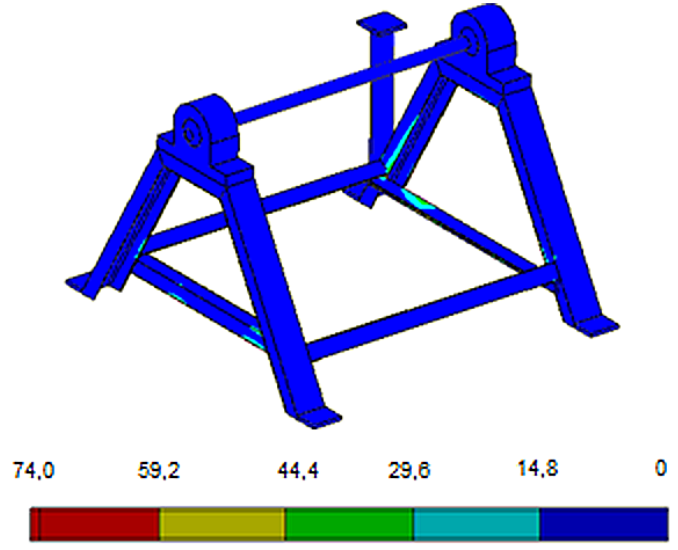

a)

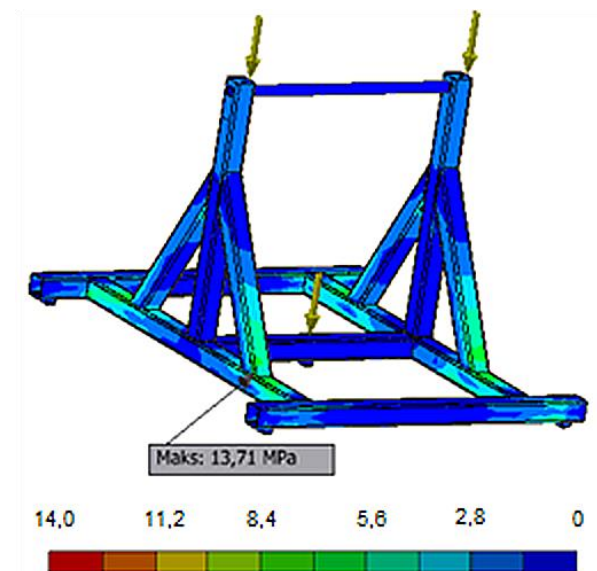

b)

Fig. 17. The stress diagram (in $M P a$ ) for the case of frame lifting: a) LDG300 granulator, b) DG750 granulator.
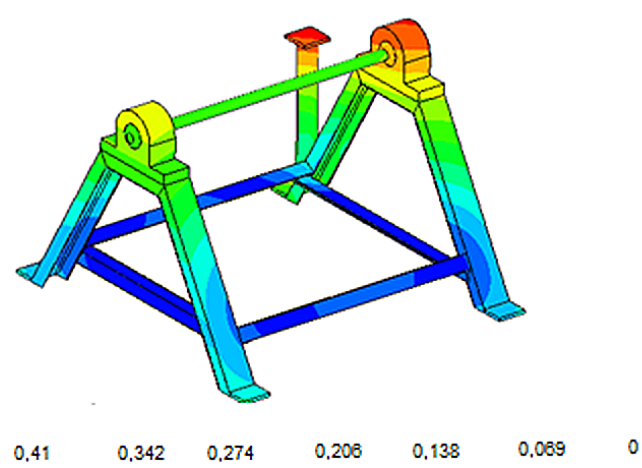

a)

b)

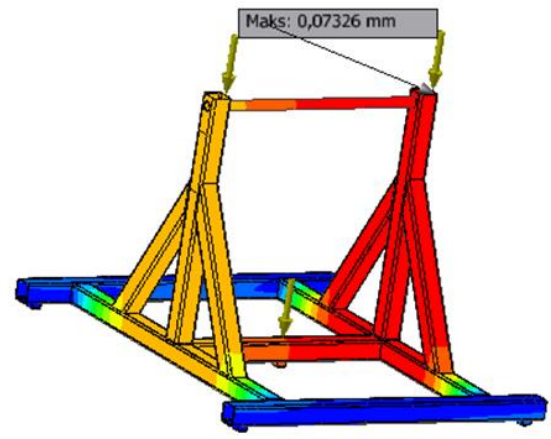

Fig. 18. The diagram of the displacements (in $\mathrm{mm}$ ) for the case of lifting the frame of: a) LDG300 granulator, b) DG750 granulator. 
linear for both granulators. When analyzing changes in displacement values the greatest are for angle of $60^{\circ}$ for the LDG300 granulator and $30^{\circ}$ for the DG750 granulator. This suggests that it is not sufficient to analyze only the extreme inclination of the axis of the granulator disc. The above observation concerns the stresses occurring in the model and displacements of its parts. In both cases of moving the granulators, the stress values turned out to be higher than the stresses for the loads of the upper and lower frames discussed above. The stresses arising when moving the granulator in relation to the highest stresses obtained in the analysis of the lower frame of the LDG300 granulator at rest are 2.89 times higher, and in the case of moving the granulator even 1.59 times higher. However, in the case of the DG750 granulator, the stresses from moving the granulator were 2.45 times larger than those for the resting granulator. For the lifting case they were 3.27 times smaller. The displacements of the frame elements of the LDG300 granulator, similarly to the stresses, turned out to be up to 3.1 times higher for displacements than in the case of the displacements calculated for the freely resting lower frame and $10 \%$ smaller for the lifting frame. The displacements in the DG750 granulator, in the case of shifting, were 3.23 times higher, and in the case of lifting, 8.14 times less than the results for the stationary granulator. The above results indicate that it is advisable to carry out additional simulations while designing the laboratory and industrial equipment to investigate specific cases related to the operation of such equipment. The frame structure should take into account additional external loads related to the individual use of the device, which are often not taken into account.

\section{REFERENCES}

Augusta, H., Nisya, F.N., Iman, R.N., Bilad C., 2017, Granulation of coal fly ash by using different types of granule agents, IOP Conference Series: Earth and Environmental Science, 65(1), 012023.

Baiul, K.V., 2019, Synthesis of roller press rational design for composite solid fuel production, Problemele Energeticii Regionale, 2(43), 103-116.

Bembenek, M., Wdaniec, P., 2019, Effect of crusher type and its parameters on the dry granulation of powders, Przemyst Chemiczny, 98(2), 310-313 (in Polish).

Bembenek, M., Wdaniec, P., Baran, E., 2020, Production of a granulated mineral fertilizer from waste gypsum in a flatmatrix granulator, Przemyst Chemiczny, 99(2), 236-238 (in Polish).

Burchart-Korol, D., 2009, Granulacja materiałów odpadowych w hutnictwie żelaza i stali, Prace Instytutu Nafty $i$ Gazu, 164, 227- 233 (in Polish).
Burchart-Korol, D., Korol, J., Francik, P., 2012, Application of the new mixing and granulation technology of raw materials for iron ore sintering process, Metalurgija, 51(2), 187190.

Ennis, B.J., 2010, Agglomeration Technology: Equipment Selection, Chemical Engineering, 117(5), 50-54

Feng, Y., 2016, The finite element analysis and optimalization of $\phi 6000$ disc pelletize's disk, Mathematical Modelling of Engineering Problems, 3(1), 10-18.

Gluba, T., 2012, Granulacja bębnowa surowców drobnoziarnistych o różnych składach ziarnowych, Zeszyty Naukowe Nr. 1116. Rozprawy Naukowe, Z. 423, Politechnika Łódzka, Łódź (in Polish).

Hatapakki, A., 2016, Design optimization of C frame of hydraulic press machine, Asian Journal of Convergence in Technology, 2(3).

Holger, L., Lampke, J., 2016, Technical and economic aspects of granulation of coal, XVIII Int. Coal Preparation Congress, ed. Litvinenko, V., Saint-Petersburg, 383-389.

Hejft, R., Leszczuk, T., 2012, Wpływ elementów zgarniających w granulatorze talerzowym na przebieg procesu, Chemik, 66(5), 370-375 (in Polish).

Karwat, B., Rubacha, P., Stańczyk, E., 2020, Simulational and experimental determination of the exploitation parameters of a screw conveyor, Eksploatacja i Niezawodnosc Maintenance and Reliability, 22(4), 741-747.

Kłassien, P.W., Griszajew, I.G.: Podstawy techniki granulacji, Wydawnictwo Naukowo-Techniczne, Warszawa (in Polish).

Leszczuk, T., 2014, Wplyw parametrów konstrukcyjno-technologicznych na proces aglomeracji $w$ granulatorze talerzowym, $\mathrm{PhD}$ theisis, Politechnika Białostocka (in Polish).

Lian, K., Fan, B., Miao, Y., Zhu, X., 2016, Research on optimal design and modal analysis of the frame, Int. Conf. on Artifical Intelligence: Technologies and Aplications, ICATIA, 272-274.

Malipatil, S.S, Potdar, Y.N, Mattikalli, A.C., 2014, Analysis and structural optimization of 5 ton $\mathrm{H}$-frame hydraulic press, Innovative Science, Engineering \& Technology, 1(5), 356360.

Obraniak, A., Gluba, T., Ławińska, K., Derbiszewski, B., 2018, Minimisation of environmental effects related with storing fly ash for combustion of hard coal, Environment Protection Engineering, 44(4), 177-189.

Ozga, M.E., Borowski, G., 2018, The use of granulation to reduce dusting and manage of fine coal, Journal of Ecological Engineering, 19(3), 218-224.

Piekut, J., Obidziński, S., Kowczyk-Sadowy, M., Suchocka, U., 2017, Granulated coffe grounds effect on selected physicochemical and functional properties of soil, Agricultural Engneering, 21(4), 73-81.

Udo, M., Esezobor, D., Afolalu, A., Onovo, H., Ongbali, S., Okokpujie, I.P., 2018, Investigation of balling characteristics of mixture of iron oxide bearing wastes and iron ore concentrates, IOP Conf. Series: Materials Science and Engineering, 413, 012042.

Xinhao, Z., Yanxiong, L., Lin, H., Hujie, M., 2016, Finite element analysis and topology optimization of a $12000 \mathrm{KN}$ fine blanking press frame, Structural and Multidisciplinary Optimization, 54, 375-389. 


\section{ANALIZA WPLYWU WARUNKÓW PRACY NA \\ NAPREŻENIA I ODKSZTALCENIA RAM \\ GRANULATORÓW TALERZOWYCH O MALEJ WYDAJNOŚCI Z WYKORZYSTANIEM MES}

\section{Streszczenie}

Powszechną praktyką konstrukcji ram urządzeń technologicznych jest ich uproszczony dobór bez obliczania warunków wytrzymałości i sztywności. Jest ona szczególnie popularna przy projektowaniu małych urządzeń. W przypadku granulacji w granulatorze talerzowym konieczne jest eksperymentalne określenie prawidłowych parametrów procesu.

Dlatego granulator talerzowy musi pracować w szerokim zakresie kątów nachylenia osi talerza granulatora względem poziomu. Wykorzystanie granulatora do celów laboratoryjnych wymaga również uwzględnienia obciążeń wynikających z jego mobilności. W odpowiedzi na to przeprowadzono analizę MES dotyczącą wpływu kąta pochylenia osi granulatora podczas jego pracy na naprężenia występujące $\mathrm{w}$ ramie laboratoryjnych granulatorów talerzowych LDG300 oraz DG750. Dodatkowo przeprowadzono analizy naprężeń ramy granulatora podczas jej podnoszenia i przemieszczania. Analizy pozwalają zidentyfikować najważniejsze obciążenia mające wpływ na prawidłowe obliczenia ram w celu uniknięcia ich przewymiarowania.

Received: August 18, 2020

Received in a revised form: October 6, 2020

Accepted: October 9, 2020 